\title{
Teaching EFL to children: reflections on (future) teachers' language assessment literacy
}

\author{
Juliana Reichert Assunção Tonelli \\ Universidade Estadual de Londrina \\ teacherjuliana@uol.com.br \\ Gladys Quevedo-Camargo \\ Universidade de Brasília \\ gladys@unb.br
}

\begin{abstract}
This article presents some reflections on the language assessment literacy of seven EFL undergraduates and one graduate teaching English to children in a university research project. The data were collected in a focus group and socio-discursively analyzed with the concept of voices underlying their answers. The voices identified were predominantly academic as the participants mirrored the knowledge and the discourse they have (had) contact with at the university. This showed full or partial appropriation of such discourses, indicating a language assessment literacy process going on. The findings highlight the tensions between the different kinds of knowledge that should be dealt with in language teacher education and the demands posed by the challenge of assessing children learning languages to the extent that they evidence problems that stem from lack of appropriate literacy assessment for this context. This is definitely a huge challenge in Brazil, as well as in many other places in the world, where undergraduate language courses have not been preparing future teachers to work with assessment.
\end{abstract}

Keywords: Language assessment literacy; EFL; Language teacher education; Teaching English to children.

\section{Resumo}

Este artigo apresenta reflexões sobre o letramento em avaliação de línguas de sete alunos de um curso de graduação em letras/inglês-licenciatura e uma mestranda em estudos da linguagem, todos envolvidos com o ensino de língua inglesa para crianças em um projeto de pesquisa universitário. Os dados foram coletados por meio de grupo focal e analisados sociodiscursivamente com a utilização do conceito de vozes subjacentes às respostas. As vozes identificadas foram 
predominantemente acadêmicas, posto que os participantes espelharam o conhecimento e o discurso com os quais tiveram contato na universidade. Tal espelhamento demonstrou apropriação total ou parcial de tais discursos, indicando um processo de letramento em avaliação de línguas em andamento. Os resultados trazem luz às tensões entre os diferentes tipos de conhecimentos que deveriam ser abordados na formação de professores de línguas e sobre as demandas apresentadas pelo desafio de avaliar crianças aprendendo línguas à medida que evidenciam problemas que se originam da falta de letramento em avaliação apropriado para tal contexto de trabalho. Esse é, sem dúvida, um enorme desafio que temos no Brasil, bem como em outras partes do mundo, onde cursos de formação de professores (de línguas) não têm preparado os futuros professores para avaliar.

Palavras-chave: Letramento em avaliação de línguas; Inglês como língua estrangeira; Formação de professores de línguas; Ensino de inglês para crianças.

\section{Resumen}

Este artículo presenta algunas reflexiones sobre la literacidad en evaluación de lenguas de siete estudiantes de un curso de formación de profesores de inglés como lengua extranjera y una estudiante de postgrado enseñando inglés a niños en un proyecto de investigación universitario. Los datos fueron recogidos en un grupo focal y socio-discursivamente analizados con el concepto de voces subyacentes a sus respuestas. Las voces identificadas fueron predominantemente académicas ya que los participantes reflejaban el conocimiento y el discurso con el que tenían contacto en la universidad. Esto mostró la apropiación total o parcial de tales discursos, indicando un proceso de literacidad en evaluación de lenguas. Los hallazgos señalan tensiones entre los diferentes tipos de conocimientos que deberían abordarse en la formación de profesores de lenguas, así como las demandas planteadas por el desafío de evaluar a los niños aprendices de lenguas extranjeras. Este es, definitivamente, un gran reto en Brasil, así como en muchos otros lugares del mundo, en donde las carreras de grado todavía siguen sin preparar a los futuros docentes para trabajar con evaluación.

Palabras clave: Literacidad en evaluación de lenguas; Inglés como lengua extranjera; Formación de profesores de lenguas; Enseñando inglés a niños.

\section{Introduction}

The teaching and learning of English as a foreign language (EFL) to children have been the subject of research in several parts of the world (see for instance BLAND, 2015; CROSSE, 2007; HASLAM; WILKIN; 
KELLET, 2005; MURPHY; EVANGELOU, 2016; SCOTT, 2009), as well as in Brazil (MELLO, 2013; ROCHA, 2006; SANTOS, 2009; TAMBOSI, 2006; TONELLI, 2005, among others). In Brazil, although optional in elementary schools, teaching English to children is part of the curriculum in most private and in some public schools, depending on local initiatives. As a consequence, there has been an increase in the number of students in the early grades of Brazilian Elementary Education learning (an)other language(s), which has generated a demand for language teachers. However, there are few EFL undergraduate courses that tackle the issue of teaching children (BACARIN, 2013; SANTOS, 2009; TONELLI, 2017; TUTIDA, 2016).

Taking the above context into account, this study was designed so as to investigate (future) EFL teachers' conceptions related to language, language learning, teaching children, assessment and reasons to assess children's language learning, what to focus on when assessing children's language learning, and the participants' perceptions about their own work in the classroom. Therefore, this article reports the data collected in a university research project in which eight (future) EFL teachers were involved with teaching children from 6 to 12 years old in a school located on a university campus ${ }^{1}$. Although not an issue at first, the need to verify students' progress came up as the project developed and the participants expressed their concerns on how to assess the language development of such young students. Considering the project was close to its end and the participants had short time availability, a focus group (KRUEGER; CASEY, 2000) was conducted.

This paper is organized into five sections. The first presents a brief literature review of studies on language teacher education in Brazil regarding the teaching of English to children. In the second, the concept of (language) assessment literacy is addressed as well as its relationship with the assessment of children learning languages. The third section is devoted to the methodology adopted in this study, along with the presentation of the participants and the procedures to analyze the data obtained. In the fourth

\footnotetext{
${ }^{1}$ In this project, the teachers' work was systematized and organized by means of didactic sequences (DOLZ; NOVERRAZ; SCHNEUWLY, 2004), which were planned, developed and implemented by the participants themselves. The genre focused on was children's story (TONELLI, 2005).
}

Horizontes de Linguística Aplicada, ano 17, n. 1, 2018 
section, the data are presented, analyzed, and discussed. The fifth and last part of this article brings reflections on the findings of this study.

\section{Literature Review}

\subsection{EFL teacher education and the teaching of EFL to children in Brazil}

Although teacher education has been widely researched in Brazil, there has not been much research on the education of teachers who work, or intend to work, with children learning languages. A search for MA dissertations and $\mathrm{PhD}$ theses on language teaching to children produced over the last 10 years in Brazilian Post-graduate Programs indicated that the studies conducted have diverse aims. Tonelli (2005), for instance, advocated the use of the textual genre 'children's story' in EFL teaching to children based on the vygostyan concepts of spontaneous and nonspontaneous knowledge. According to Tonelli (2005, p. 199), "teaching English by means of children's stories is a powerful tool to develop students' spontaneous knowledge leading them to non-spontaneous concepts". 2

The study by Linguevis (2007) focused on language teaching and learning conceptions that guided an English teacher's practicum. The author also investigated children's language learning conceptions as well as whether they were in accordance with the school principles. Forte (2010), also concerned with beliefs, analyzed the teaching of EFL to children, examined the use of language to promote literacy in English, along with teachers', students', parents', and school coordinators' views. In her conclusions, she states that 'the parents', the teachers' and the school coordinators' beliefs are relevant but need to be heard within the school context in order to produce an effective and pleasurable learning to students" (p. 108).

Andrade (2011) had a similar aim, as she discussed beliefs, experiences and actions connected to the public education context and their impact not only on the teaching and learning processes but mainly on the

\footnotetext{
${ }^{2}$ All the citations from texts that were originally written in Portuguese have been translated by the authors of this article for publication purposes.

Horizontes de Linguística Aplicada, ano 17, n. 1, 2018 
teachers' educational process. The author states that "it is urgent that universities offer courses to prepare English teachers to work in the initial years of schooling" (p.114).

Other studies that should also be mentioned are Pires (2001), Rinaldi (2011), Santos (2009) and Tutida (2016). Pires (2001) discussed the fact that teaching a foreign language to young learners is risk-taking since teachers of English do not have specific education to teach them. Hence, when the teacher is an expert in language but lacks experience in preschool education, children might take aversion to the foreign language. On the other hand, when the teacher provides pleasurable and playful classes but makes pronunciation or grammar errors, for instance, children tend to value what is taught as truth. In both cases, children's future as foreign language students might be placed at risk. states that

those who finish an undergraduate degree in Languages and Literature or a good free English course and have a great curriculum in language can be well prepared for teaching adults and teenagers, but may have no knowledge about education of children under six years old. Although those who attended a teaching course or pedagogy and/or some other course in early childhood education can be excellent teachers for children up to six years old, they do not have sufficient knowledge of English to teach (p. 7) $)^{3}$.

According to the author, teachers of English to children should not only have a good level of language knowledge but also know how to deal with students in their first years of schooling. She asserts that if the teacher does not know children's cognitive, physical and emotional characteristics, s/he may cause serious consequences.

Santos (2009) described and analyzed the kind of knowledge necessary for language teachers to work with children. The study was conducted with five public school teachers. The results showed that the teacher's role in that context is challenging, given the lack of specific teacher education to work with these children. In the author's words,

${ }^{3}$ In accordance with the Brazilian Statute of the Child and Adolescent (BRASIL, 1990), a child is every person under 12 years old.

Horizontes de Linguística Aplicada, ano 17, n. 1, 2018 
to teach English to children, teachers are required to have very specific knowledge - including mastering the English language itself - and since in Brazil English Language undergraduate courses do not offer specific initial education to English teachers to children, it is quite common to hear teachers complain about how difficult they find to teach them (SANTOS, 2009, p. 56).

In this regard, Rinaldi (2011) stated that, in order to be hired as a teacher to work with any foreign language in the first years of schooling, the teacher has to have a university degree in the target language. She states that "to pay attention to the quality and specificity of teacher education for this context is crucial, since lack of appropriate education may, as a consequence, yield professionals performing in an inadequate way with this public" (p.33).

Tutida (2016) reported her own experience as a newly graduate English teacher. She reflected on the challenges faced when she was offered a job as an English teacher to children and, despite having a degree in English Language and Literature, she had no confidence since the course did not offer anything related to that teaching field. Her study also emphasizes the urgency for specific education to teach children and pointed out the desirable knowledge English language teachers should master.

The studies briefly presented in this section highlight the importance to prepare teachers to face the specific challenges of teaching languages to children. This leads us to the next section, which discusses (language) assessment literacy.

\section{2 (Language) Assessment Literacy and the challenge of assessing children's language learning}

The concept of assessment literacy first appeared in an article published by Stiggins (1991), and has been defined by various researchers. According to Stiggins (2002) and Popham (2004), the concept refers to an understanding of the principles governing solid, well-informed and fair assessment. For Coombe, Troudi and Al-Hamly, (2012), "implicit in this definition is that assessment-literate teachers have the know-how and understanding needed to assess their students effectively and maximize learning" (p. 22) 
For Stiggins (2007), solid, well-informed and fair assessment is characterized by five elements: first of all, it should originate from, and serve, clear purposes; second, it should originate from, and reflect, clear and appropriate performance objectives; third, it should be based on an appropriate assessment method (for the purpose and objectives); fourth, it should depict students' achievement properly; and fifth, it should exercise control over all relevant sources of bias and distortions.

Therefore, a literate teacher in terms of assessment knows what $\mathrm{s} / \mathrm{he}$ is assessing, why s/he is assessing, what the best way to assess certain aspects of the teaching and learning process is, how to generate reliable data on students' performance, what can go wrong and how to prevent potential problems.

Popham (2009) emphasizes that teachers should be aware that the term assessment does not refer merely to traditional paper-and-pencil tests, i.e., assessment is not synonymous with testing, as "an assessment might consist of a wide variety of evidence-eliciting techniques" (p. 5).

The author considers two types of assessment as a framework for the development of assessment literacy: classroom assessments and accountability assessments. The former refers to formal and informal procedures used by teachers in order to, ideally, make accurate inferences about their students' knowledge and abilities, though often such procedures are used merely as a means to produce grades. The latter are used to refer to generally standardized measurement devices used by governmental entities to find out whether the efforts to achieve educational goals are being successful.

According to Popham (2009), the decisions teachers have to make in relation to assessment are directly linked to those two types of assessment and such decisions have a direct impact on the way students are taught. In his own words,

Both of these clusters of decisions have a meaningful impact on the way students end up being taught. Because assessmentliterate teachers will typically make better decisions, and because we want students to be better taught, it should be obvious that today's teachers must acquire more assessment literacy — and the sooner, the better (POPHAM, 2009, p.6). 
Therefore, the more teachers know about classroom assessments and accountability assessments, the better their decisions will be.

Children who are learning foreign languages have different needs from older learners because, although any age group needs some kind of feedback from the teacher regarding their strengths and weaknesses, children, in general, need more help and support to understand what and how they need to learn. In addition, it is necessary to keep them interested in what they are doing, since it is more likely that they feel discouraged in face of adverse feedback or some failure (HASSELGREEN, 2012).

To Hasselgreen (2012), assessing children language learning is a very rewarding and special work, but presents many challenges. This work involves knowledge of the target audience's characteristics, which will determine both the type of tasks and feedback. It also involves the language skills you expect children to acquire as well as the specific purposes of learning at their age. In addition, in Hasselgreen's words,

as the age of learning new languages has been consciously lowered by education policymakers, additional assessment demands have been placed on primary school teachers. Investment and research are needed to ensure that these teachers have training and tools to effectively carry out a wide range of assessment practices (HASSELGREEN, 2012, p.175).

This view reinforces the importance to develop studies in this area.

\section{Method}

The data for this study were collected by means of a focus group. As mentioned previously, the participants were part of a university project and were teaching English to children. During the project regular meetings, they expressed concerns on how to assess their students' language development. Therefore, although aware of the limitations a single focus group might represent in terms of data generation and validity, our intention was to provide a snapshot of the participants' perceptions and views that had already been expressed in other occasions.

According to Krueger and Casey (2000), a focus group (FG) is a research technique used to obtain qualitative data from group sessions. The 
groups, which should not have more than 10 people, should consist of participants with common features. There must be the presence of a moderator, whose role is to promote everyone's participation, maintain a focus on the discussion goals, as well as preventing the monopolization of the conversation by some participants over others. The moderator should use a set of questions to engage participants and follow a sequence, ideally from general to specific issues, leading the participants to express their ideas, experiences, feelings, perceptions, preferences, values, and difficulties related to the theme.

The questions and the focus group were in Portuguese because the research was conducted at a Brazilian university with students whose first language is Portuguese. The participants were informed of the aims of the meeting - to collect information on their views on language as well as on the assessment of children learning EFL - and agreed to participate. The participants did not have access to the questions previously. For ethical reasons, all names of the participants are pseudonyms.

The questions ${ }^{4}$ asked to the group are shown in Table 1.

\section{Table 1. Questions asked in the Focus Group}

\section{QUESTIONS}

1 What is language ${ }^{5}$ ?

2 What is it to learn a (foreign) language?

3 How should children be taught (foreign) languages?

$4 \quad$ What is it to assess?

5 Why assess children's (foreign language) learning?

6 What should be assessed in children's (foreign language) learning?

$7 \quad$ What should we do with the assessment outcomes?

8 How is assessment happening in our classrooms? Are we assessing?

9 Would you like to make any further comment on the assessment of children's (foreign language) learning?

Source: the authors

Questions 1 to 5 intended to investigate the participants' conceptions related to language, foreign language learning, teaching children, assessment and reasons to assess children's foreign language

\footnotetext{
${ }^{4}$ All the translations in this paper are the authors' responsibility.

${ }^{5}$ In Portuguese, the word used in questions 1 and 2 was 'língua' (language in the sense of a people's oral and written means of communication).
}

Horizontes de Linguística Aplicada, ano 17, n. 1, 2018 
learning. This was important because such conceptions underlie, guide and affect every single aspect of the work carried out by the teacher in the classroom. Questions 6 and 7 aimed at obtaining information on what to focus on when assessing children's foreign language learning. These questions intended to obtain information on whether the participants reached an agreement on criteria to be adopted to assess their students' language development. Question 8 was designed to provide information on the participant's perceptions about their own work in the classroom, so that a comparison could be made between their statements in the previous questions and their report about their classroom actions. Question 9 was included to allow the participants to add extra information or express further opinions on what they considered relevant.

The focus group was held on October 9th, 2014 at a Brazilian university. It took approximately 3 hours and was moderated by the project coordinator $^{6}$. It is important to register that, although the time was relatively short in terms of generating valid data, in this section, we aimed at knowing the general participants' conceptions. There were eight participants, whose profiles are presented in Table 2.

Table 2. Focus group participants' profiles

\begin{tabular}{|c|c|c|c|c|}
\hline PARTICIPANT & AGE & GENDER & $\begin{array}{c}\text { EDUCATION } \\
\text { STATUS }\end{array}$ & $\begin{array}{l}\text { TEACHING } \\
\text { EXPERIENCE? }\end{array}$ \\
\hline ANNABEL & 25 & Female & Graduate & Yes \\
\hline CAROL & 23 & Female & Undergraduate & Yes \\
\hline HIROKO & 21 & Female & Undergraduate & No \\
\hline JOHN & 20 & Male & Undergraduate & No \\
\hline LAURA & 30 & Female & Undergraduate & No \\
\hline SUZY & 27 & Female & Undergraduate & No \\
\hline TINA & 23 & Female & Undergraduate & Yes \\
\hline TONY & 19 & Male & Undergraduate & Yes \\
\hline
\end{tabular}

Source: the authors

As Table 2 shows, the participants were six women and two men. Their age ranged from 19 to 30 years old. Half of the women reported having some experience with teaching English to children outside the

\footnotetext{
${ }^{6}$ The project coordinator was Juliana Tonelli, first author of this article.

${ }^{7}$ Outside the teaching project.
} 
project, whereas one of the men had had experience with teaching English to children outside the project. Annabel, the only graduate in the group, was doing an MA on Language Studies at the time the focus group was held.

The discussion was recorded with the participants' permission and transcribed by the moderator herself. The transcription was analyzed from a socio-discursive perspective by using indexes of voices at the enunciative level of the text. According to Machado and Bronckart (2009, p.326), voices are "entities that take over (or to which are attributed) the responsibility of what is being said", i.e., the voices in a text are held responsible for what is expressed. A text can have one or several voices, which can be expressed directly or indirectly by means of explicit or implicit (linguistic) marks respectively.

As far as teachers are concerned, Bohn (2005) states that the voices they usually express are from their undergraduate teachers, the authors studied during their undergraduate courses, the educational institutions they belong to, educational or governmental authorities, the society, their families, and their university or work colleagues. Taking into account the aim of the focus group, the unveiling of such voices was an important tool.

The analyses of the transcriptions are displayed in Table 3.

The analyses of the transcription revealed two voices: academic and personal, as shown in Table 3. The academic voices indicated full or partial appropriation of the discourse commonly disseminated in the participants' academic environment, which basically consisted of the university professionals they had contact with and authors they were exposed to. The personal voices consisted of their own ideas, uncertainties and dilemmas about the issue being discussed. 
Table 3. Classification of voices used in this study

\begin{tabular}{|c|c|c|c|c|}
\hline & SOURCE & $\begin{array}{c}\text { LINGUISTIC } \\
\text { MARKS }\end{array}$ & TOPIC & EXAMPLE \\
\hline 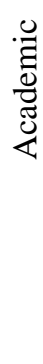 & $\begin{array}{l}\text { External } \\
\text { instance: } \\
\text { academia }\end{array}$ & $\begin{array}{l}\text { Verbs in the simple } \\
\text { present with generic } \\
\text { meaning; use of first } \\
\text { person plural; use of } \\
\text { passive voice; use of } \\
\text { impersonal } \\
\text { constructions }\end{array}$ & $\begin{array}{l}\text { Presentation of } \\
\text { facts of truths; } \\
\text { standard } \\
\text { discourse }\end{array}$ & $\begin{array}{l}\text { Language is what } \\
\text { we constitute and } \\
\text { what constitutes } \\
\text { us (...) } \\
\text { Social } \\
\text { relationships are } \\
\text { established } \\
\text { through language. } \\
\text { [Annabel] }\end{array}$ \\
\hline 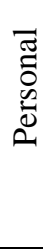 & $\begin{array}{l}\text { Internal } \\
\text { instance: } \\
\text { the } \\
\text { enunciator }\end{array}$ & $\begin{array}{l}\text { Verbs in the simple } \\
\text { present; use of first } \\
\text { person singular, time } \\
\text { markers }\end{array}$ & $\begin{array}{l}\text { Doubts; } \\
\text { personal } \\
\text { opinion, } \\
\text { references to } \\
\text { personal } \\
\text { experiences }\end{array}$ & $\begin{array}{l}\text { To classify? (...) } \\
\text { when I think } \\
\text { about assessment, } \\
\text { I think about } \\
\text { classification }\end{array}$ \\
\hline
\end{tabular}

Source: Adapted from Quevedo-Camargo (2011, p.60).

The next part presents the data and discusses such voices in a more detailed way.

\section{Data presentation, analysis and discussion}

The data will be presented following the sequence of the nine questions asked in the focus group. Excerpts from the transcription will be used as illustrations.

\subsection{Question 1: What is language?}

The answers to this question indicated that the participants were not clear in relation to the distinction between concepts of language (oral and written production in English or Portuguese, for instance) and language (broader concept of communication). They mentioned language as a means 
of communication, a form of culture, as a social and personal constituent, and as a type of language (broader concept of communication).

The voices that stood out were predominantly from the participant's undergraduate teachers and their university readings, which were categorized in this study as 'academic voices'. Excerpt 1 shows an example of such voices in Annabel's (the only graduate participant) answer.

\section{Excerpt 1}

Language is what we constitute and what constitutes us, by which we communicate with other people in social situations. Why do we have language? Because we are social beings and without it, how would we communicate? Language can be both written and oral, but it serves communication. Social relationships are established through language. [Annabel]

It is possible to observe that, although Annabel incorporated knowledge and concepts from her academic environment, she seems to mix the ideas of language (in Portuguese 'língua' such as English or Spanish) and language (in Portuguese 'linguagem', the broader concept). This has implications for her teaching practice, as a clear understanding of these concepts influences pedagogical decisions.

\subsection{Question 2: What is it to learn a (foreign) language?}

There were not many answers to this question. The two participants who spoke (Annabel and Carol) agreed that a language is a set of structures that should be learned for communication. As shown in Excerpt 2, they mentioned communication, interaction, a relatively fixed structure, message transmission, which might point to some confusion and contradiction in terms of what they believe learning a language is, i.e., form versus use.

\section{Excerpt 2}

(...) a language is a reasonably fixed structure that is used for communication... learning a language is knowing this language enough to be able to communicate. For example, I can read a text and understand... I can convey a message to that person using this language [Annabel] 
Using interaction. [Carol]

The voices underlying Annabel's and Carol's statements seemed, again, to stem from their academic background, as they mirrored what is normally advocated by Brazilian university language professionals.

\title{
4.3 Question 3: How should children be taught (foreign) languages?
}

The participants mentioned that EFL should be taught to children so as to arouse interest and make them involved by teaching in a playful and meaningful way. They also criticized decontextualized vocabulary teaching, as shown in Excerpt 3.

\section{Excerpt 3}

(...) in an interesting way so that they feel involved (...) a more playful way (...) [Laura]

A way that brings the child's reality (into the classroom) as well [Suzy]

The idea that teaching kids is only teaching random words (...) because they won't know anyway (...) [Hiroko]

Taking into account that neither Laura, Suzy nor Hiroko reported having had any previous teaching experience outside the project reported here, the voices underlying their answers seemed to stem from their academic environment.

\subsection{Question 4: What is it to assess?}

The following elements were used by the participants to define what to assess is: measure knowledge, find problems, classify students, attain an objective, set goals, and verify student's aptitude to solve tasks or answer questions.

Although not developed further, the idea that there are different types of assessment was mentioned, as shown below.

\author{
Excerpt 4 \\ Measure knowledge? [Laura] \\ To find flaws, maybe. [Hiroko]
}

Horizontes de Linguística Aplicada, ano 17, n. 1, 2018 
To classify? (...) when I think about assessment, I think about classification (...) till the end of the term, if all the students get to a certain level (...) through assessment I would classify them, those who got to that level, those who didn't. [Tina]

The teacher gives a situation to the student and sees if she can or cannot solve it (...) according to what the teacher wants. He has to have this objective established in advance. [Tony]

Assessing is to establish an objective. It's trying to build with the students ways by which they can achieve this objective, then use an instrument to see if they achieved it or not, and then try to interpret that (...)[Annabel]

(...) it depends... what kind of assessment you're going to use (...) Do you want to diagnose? (...) Then you're going to... there are two kinds, right? To classify... summative and classif... summative? It depends on your objective... I think all of them are valid (...)[Carol]

It was possible to identify personal voices in Laura's, Hiroko's and Tina's answers, as they expressed uncertainty in relation to what they think assessment is by using questions (Laura and Tina) and the word 'maybe' (Hiroko). As for the other three participants - Tony, Annabel and Carol -, the voices that stood out were academic. It is interesting to notice that Carol appeared to be in the middle of an appropriation process in relation to the academic discourse and to theoretical principles of assessment. Annabel, however, demonstrated full appropriation of the academic discourse.

\subsection{Question 5: Why assess children's (foreign language) learning?}

In general, the participants agreed that it is important to have a specific moment to assess children's language learning in order to check if the objectives were being met, if practice was in accordance with the objectives, and if the teacher's methods were appropriate. They also mentioned that children's learning does not necessarily happen because the teacher knows how to teach and that by assessing the students the teacher will also be assessing his/her own work.

\section{Excerpt 5}


You don't necessarily need an assessment instrument like a test. But you've got to assess whether your children are or not achieving the aims you established for them (...)[Annabel]

You can see if your practice is leading the students to achieve what you established [Carol]

Mainly with children, right? Because sometimes you, the teacher, think your methods are being... [John]

\section{Appropriate [Carol]}

The participants' words above seemed to be embedded with academic voices. However, later in the discussion, one participant - Laura spoke against assessing children's language learning. She mentioned a student of hers who changed his behavior from one term to the other due to the arrival of his newborn brother. She argued that, if she had to assess this boy's language development, she might misjudge him, as he stopped producing language and participating in class activities due to this family event. In this case, Laura might be expressing both her personal and academic voices, as she raised an important issue to be considered as an assessor: children's lives.

\section{Excerpt 6}

I don't think we should have assessment for children (...) at their age (...) because learning a language is a process. And at their age, they might not be able to show it. They may be keeping that deep inside and, later on, when they decide to express themselves... because we have a student that, at the beginning of the term he used to speak a lot! Before I finished explaining he would answer promptly! Now he doesn't anymore because his baby brother was born and this has somehow blocked him. [Laura]

There was, however, a counter-argument to the idea put forth by Laura. As shown in the next excerpt, Carol stepped back and stated she believed that assessing children was important exactly because of such external influences. For her, a child's change in behavior should be acknowledged and taken into account when assessing their learning progress. This point was reinforced by John, who said that the 
acknowledgement of the existence of external factors was a type of assessment already. Both Carol and John expressed academic voices.

\section{Excerpt 7}

(...) coming back to what Laura said... that we shouldn't assess children because of that (family event), that's exactly why we should assess them. These changes in behavior say a lot about the children and we should assess that too! [Carol]

In a way, you're bringing that to your classroom... the moment you knew about the little brother you were already assessing the student... look, it's not that he doesn't know... but this is a kind of assessment already, I think. [John]

As observed, the participants seemed to agree that assessing children to keep track of the language learning objectives was important. However, at the same time, they brought about other issues that revealed concerns stemming from their classroom practice during the teaching project. It seems, therefore, that dilemmas and concerns spoke much louder than their academic voices when it came to saying why we should assess children's language progress.

\subsection{Question 6: What should be assessed in children's (foreign language) learning?}

One of the participants mentioned that it was not only language that should be assessed, but other aspects such as insufficient development of motor coordination. She also expressed the idea that a student should only be compared in relation to him/herself, not to others.

\section{Excerpt 8}

I think there's no way to ... assess only language... I mean, you can do it but only after you assess in general terms, I mean, socialization, motor coordination... [Carol]

Comparing him with himself... [Carol] 
In this case, Carol's opinion seemed to mirror academic voices when advocating a holistic approach to assessing children's language learning.

\title{
4.7 Question 7: What should we do with the assessment outcomes?
}

In general, the participants seemed to agree that assessment outcomes should be used to change, maintain, reinforce, or adapt classroom practice, as shown in the excerpt below.

\author{
Excerpt 9 \\ Depending on the result, change your practice... [John] \\ Or keep it... [Carol] \\ Or keep it and reinforce it... [John] \\ Or adapt it... [Hiroko]
}

Again, the ideas expressed in Excerpt 9 pointed to academic voices as such ideas are generally present in the official academic discourse about assessment. This was strong evidence of the (language) assessment literacy process these students were going through.

\subsection{Question 8: How is assessment happening in our classrooms? Are we assessing?}

By analyzing the participants' comments to this question, it was possible to notice that they were thinking of formal assessment of linguistic aspects. The project coordinator, who was conducting the focus group, drew their attention to the fact that actually, in the research project, they were not assessing the children's language learning, as none of the activities or practices adopted in the course of the project had been designed or planned to function as assessment. Although instructed to keep a reflexive diary and have portfolios for the children, these instruments were being used as a tool for general reflection on classroom practice and as a collection of activities respectively. These comments are shown in Excerpt 10. 


\section{Excerpt 10}

(...) we don't have an assessment instrument... it's observation... (...) we are not using the portfolios as assessment instruments... what are the portfolios for? [Project coordinator]

A collection of activities [Carol]

In this excerpt, both the project coordinator's voice and the participant's voice were clearly academic, as they were talking about what was (or not) done in the project.

\subsection{Question 9: Would you like to make any further comment on the assessment of children's (foreign language) learning?}

The participants' comments at the end of the focus group emphasized that, when teaching EFL to children, it is necessary (1) to spend a few minutes after class to reflect on what was done and what happened, and (2) to establish objectives and criteria to verify children's language learning progress.

\section{Excerpt 11}

I think... it's an issue we should discuss more... about criteria... (...) why I'm doing this and what I want to get from it ... and that's how (...) you get to establish your aims and criteria, right? (...) as we aren't clear about our objectives, our criteria, each of us ends up being judgmental... [Annabel]

Every assessment needs criteria ... so that I can take an activity and know what I'm looking for (...) [Tony]

As observed in the excerpts above, both Annabel and Tony were embedded with academic voices. In fact, by taking a bird's eye view on the focus group transcription, it is possible to say that the participants' answers to eight out of the nine questions were clearly embedded with academic voices. That would be perfectly expected, considering the context they were inserted in (a focus group being recorded) and the fact that they were taking part in a conversation being conducted by the coordinator of the project they belonged to. 
We should now go back to the reasons for the nine questions asked and check the achievement (or not) of our objectives and the outcomes obtained. That is presented in table 4.

As seen in the Table 4, the participants' answers showed the need for a good deal of support to develop their knowledge in relation to language assessment and assessment of children's EFL learning in particular.

As mentioned at the beginning of this article, the teaching and learning of EFL to children have been widely researched in Brazil as well as in several other countries. Hasselgreen (2012) states that, as "a research field, YLL [Young Language Learner] assessment is modest" (p. 173), with some increase after the 1990s though. Rea-Dickins (2000) and Cameron (2001) are examples of authors that have emphasized the importance of teachers' professional development in this area. However, no studies in Brazil have focused on the competences of (future) (English) language teachers to assess children's (English) language development. This study, though limited in many aspects, represents a contribution to the Brazilian English language teaching context and corroborates Hasselgreen (2012), who says that the competence of the teacher as evaluator of children learning languages can be problematic, since very often s/he does not have appropriate literacy assessment for this context. 
Table 4. Objectives and outcomes of the focus group

QUESTION OBJECTIVE OUTCOME

1) What is language?

2) What is it to learn a (foreign) language?

3) How should children be taught (foreign) languages?

4) What is it to assess?

5) Why assess children's (foreign language) learning?

6) What should be assessed in children's (foreign language) learning?

7) What should we do with the assessment outcomes?

The answers to Questions 1 and 2 indicated the participants need more support in relation to their conceptions of language and language learning.

Investigate the participants' conceptions related to language, language learning, teaching children, assessment and reasons to assess children's language learning

The answers to Question 3 showed the participants were aware that teaching EFL to children requires contextualization, arousal of interest and promotion of a pleasant classroom environment.

The answers to Questions 4 and 5 indicated that the participants need more support in relation to what assessment entails, as well as the reasons to assess children's language learning.

The answers to Question 6 revealed that the participants need more support in relation to what to assess when teaching English

Obtain information on what to focus on when assessing children's language learning to children, particularly in terms of selection of criteria.

The answers to Question 7 showed that, in theory, the participants were fully aware of what should be done with assessment outcomes. 


\section{QUESTION}

8) How is assessment happening in our classrooms? Are we assessing?

9) Would you like to make any further comment on the assessment of children's (foreign language) learning?

OBJECTIVE

OUTCOME

Provide information on the participants' perceptions about their own work in the classroom

The answers to Question 8 indicated that assessment issues were not considered in this teaching project. Therefore, language assessment had not been systematized.
Allow the participants to add extra information or express further opinions
The participants' comments revealed they were aware of the need to have more guidelines to assess children's language development.

Source: the authors 


\section{Final considerations}

This article presented the thoughts, concerns and dilemmas of seven EFL undergraduates and one graduate taking part in a university research project teaching English to children between 6 and 12 years old. Their participation in a focus group led to reflections on the need for teacher education to work with issues such as conceptions of language, language learning and assessment, how to make decisions regarding what and how to assess specific age groups, how to use language assessment outcomes for students' language development benefit, and the need to plan and systematize assessment prior to the beginning of a language course.

The participants' concerns also included the fact that language learning is a process and, therefore, children might not show progress when expected, that there are changes in children's behavior due to external (family) facts and it is impossible to have control over such facts. In addition, they mentioned teachers' feeling of guilt in face of a child's lack of progress and the existence of what is known as silent period ${ }^{8}$.

Overall, the participants expressed the influence of academia in the majority of their answers, as they mirrored the knowledge and the discourse they have (had) contact with at the university environment, showing full or partial appropriation of such discourses. The academic voices indicated some language assessment literacy under construction.

Despite the limitations of this study, mainly the fact that it consisted of only eight participants and a single instrument to collect data, it provided important insights and evidenced issues that need to be further investigated when teaching languages to children, such as what, when and how to assess them, mainly in pre-service language teaching education. This is definitely a huge challenge in Brazil, as well as in many other places in the world, where undergraduate language courses have not been preparing future teachers to work with assessment.

Therefore, assuming that assessment is a crucial component in any teaching and learning process as well as in language teacher education (BECKER, 2015; QUEVEDO-CAMARGO, 2011; SCARAMUCCI, 1999; 2006 , among others), it is important to open our eyes to the fact that the

${ }^{8}$ Reference to the idea, usually associated with Stephen Krashen, that there is a period in which learners do not attempt to speak the language being learned during the first stages of acquisition (KECK; KIM, 2014).

Horizontes de Linguística Aplicada, ano 17, n. 1, 2018 
more demands arise in the language teaching area in terms of variety of students - child, elderly, deaf, blind, adolescent or adult, the more teachers should know about what, how, why, and when to assess language development.

\section{References}

ANDRADE, M. E. Muito além da ribalta: crenças de terceiros, segundos e primeiros agentes sobre o processo de ensino-aprendizagem de inglês para crianças. 2011. 160 f. Dissertação (Mestrado em Linguística Aplicada) Instituto de Letras, Universidade de Brasília, Brasília, 2011.

BACARIN, M.C. Formação de professores de inglês para crianças: caminhos a percorrer. 2013. 54 fls. Monografia (Especialização em Ensino e Aprendizagem da Língua Inglesa) - Faculdade de Letras, Universidade Norte do Paraná, Londrina. 2013.

BECKER, C. Assessment and portfolios. In: BLAND, J (Org.) Teaching English to young learners: critical issues in language teaching with 3-12 year olds. 1. ed. London: Bloomsbury Publishing, Plc, 2015. p. 261-278.

BLAND, J. Teaching English to young learners: critical issues in language teaching with 3-12 year olds. 1. ed. London: Bloomsbury Publishing, Plc, 2015.

BOHN, H. I. A formação do professor de línguas: a construção de uma identidade profissional. Investigações: Linguística e Teoria Literária, Recife, v. 17, n. 2, p. 97-113, jul. 2004

CAMERON, L. Teaching language to young learners. 1st ed .Cambridge: Cambridge University Press, 2001.

COOMBE, C.; TROUDI, S.; AL-HAMLY, M. Foreign and second language teacher assessment literacy: issues, challenges, and recommendations. In: COOMBE, C; DAVIDSON, P; O'SULLIVAN, B; STOYNOFF, S. (Eds.). The Cambridge guide to second language 
Teaching EFL to children...

assessment. 1. Ed. Cambridge: Cambridge University Press, 2012. p. 2029.

CROSSE, K. Introducing English as an additional language to young children. 1. ed. London: Paul Chapman Publishing, 2007.

DOLZ, J., NOVERRAZ, M.; SCHNEUWLY, B. Sequências didáticas para o oral e a escrita: apresentação de um procedimento. In: DOLZ, J; SCHNEWELY, B. (Org.), Gêneros orais e escritos na escola. 2. ed. Campinas: Mercado das Letras, 2004. p. 95-128.

FORTE, J. S. O ensino de língua inglesa para alunos da educação infantil em Porto Alegre: uma leitura crítica acerca do uso da linguagem, do letramento e de crenças. 2010. 122 f. Dissertação (Mestrado em Linguística Aplicada) - Instituto de Letras, Universidade Federal do Rio Grande do Sul, Porto Alegre, 2010.

HASLAM, L; WILKIN, Y; KELLET, E. Teaching children English as an additional language: meeting the challenge in the classroom. 1. ed. London: Routledge, 2008.

HASSELGREEN, A. Assessing young learners. In: COOMBE, C; DAVIDSON, P; B. O'SULLIVAN, B; STOYNOFF, S. (Eds.). The Cambridge guide to second language assessment. 1. ed. Cambridge: Cambridge University Press, 2012. p. 171-177.

KECK, C; KIM, Y. Pedagogical grammar. 1. ed. Amsterdam/Philadelphia: John Benjamin Publishing Company, 2014.

KRUEGER, R. A; CASEY, M. A. Focus groups : a practical guide for applied research . 3. ed. Thousand Oaks: Sage Publications, 2000.

LINGUEVIS, A. M. Vamos ouvir a voz das crianças sobre aprender inglês na educação infantil. In: TONELLI, J; RAMOS, S. G. M. (Org.). $O$ ensino de LE para crianças: reflexões e contribuições. 1. ed. Londrina: Moriá, 2007. p. 85-106. 
MACHADO, A.R; BRONCKART, J. P. (Re-)Configurações do trabalho do professor construídas nos e pelos textos: a perspectiva metodológica do grupo ALTER-LAEL. In: MACHADO, A. R; ABREU-TARDELLI, L. S; CRISTOVÃO, V.L.L (Org.). Linguagem e educação: o trabalho do professor em uma nova perspectiva. Campinas: Mercado de Letras, 2009. p. 31-37.

MELLO, M. G. Ensino de inglês nos anos iniciais do Ensino Fundamental: um estudo de política pública no município de Rolândia, PR. 2013. $151 \mathrm{f}$. Dissertação (Mestrado em Estudos da Linguagem) - Universidade Estadual de Londrina, Londrina, 2013.

MURPHY, V.A; EVANGELOU, M. Early childhood education in English for speakers of other languages. 1. ed. London: British Council, 2016.

PIRES, S. S. Vantagens e desvantagens do ensino de língua estrangeira na educação infantil: um estudo de caso. 2001. 131 f. Dissertação (Mestrado em Estudos da Linguagem) - Instituto de Letras, Universidade Federal do Rio Grande do Sul, Porto Alegre, 2001.

POPHAM, W. J. All about accountability: why assessment illiteracy is professional suicide. Educational Leadership. North Beauregard St. Alexandria, v. 62, n. 1, s/p, setembro, 2004. Disponível em: <http://www.ascd.org/publications/educationalleadership/sept04/vol62/num01/Why-Assessment-Illiteracy-IsProfessional-Suicide.aspx >. Acesso em: 13 maio 2018.

POPHAM, W. J. Assessment literacy for teachers: faddish or fundamental? Theory Into Practice, The College of Education and Human Ecology, The Ohio State University, v. 48, n. 1, p. 4-11, 2009.

QUEVEDO-CAMARGO, G. Avaliar formando e formar avaliando o (futuro) professor de língua inglesa: elementos para um construto. 2011. 364 f. Tese (Doutorado em Estudos da Linguagem) - Universidade Estadual de Londrina, Londrina, 2011. 
REA-DICKINS, P. Assessment in early years language learning contexts. Language Testing, v. 17, n. 2, p. 115-122, 2000.

RINALDI, S. O futuro é agora: possíveis caminhos para a formação de professores de espanhol como língua estrangeira para crianças. 2011. $261 \mathrm{f}$. Tese (Doutorado em Linguagem e Educação) - Faculdade de Educação da Universidade de São Paulo, São Paulo, 2011.

ROCHA, C. H. Provisões para ensinar e aprender LE no Ensino Fundamental de $1^{a}$ a $4^{a}$ séries: dos parâmetros oficiais e objetivos dos agentes. 2006. 340 f. Dissertação (Mestrado em Linguística Aplicada) Instituto de Estudos da Linguagem, Universidade Estadual de Campinas, Campinas, SP, 2006.

SANTOS, L. I. S. Língua inglesa em anos iniciais do Ensino Fundamental: fazer pedagógico e formação docente. 2009. 276 f. Tese (Doutorado em Estudos Linguísticos). - Instituto de Biociências, Letras e Ciências Exatas, Universidade Estadual Paulista Júlio de Mesquita Filho, São José do Rio Preto, 2009.

SCARAMUCCI, M. V. R. Avaliação: mecanismo propulsor de mudanças no ensino/aprendizagem de línguas estrangeiras. Contexturas, São Paulo, p. 75-81, 1999.

SCARAMUCCI, M.V.R. O professor avaliador: sobre a importância da avaliação na formação do professor de língua estrangeira. In: ROTTAVA, L; SANTOS, S. S (Org.), Ensino-aprendizagem de línguas: língua estrangeira. Ijuí: Editora da UNIJUI, 2006. p. 19-64.

SCOTT, C. Teaching English as an additional language: a programme for 7-11 year olds. 1. ed. London: Routledge, 2009.

STIGGINS, R. J. Assessment literacy. The Phi Delta Kappan, v. 72, n. 7, p. 534-539, 1991.

STIGGINS, R. J. Assessment crisis: the absence of assessment for learning. The Phi Delta Kappan, v. 83, n. 10, p. 758-765, 2002. 
STIGGINS, R. J. Conquering the formative assessment frontier. In: MCMILLAN, J (Ed.). Formative classroom assessment. 1. ed. New York: Columbia University Teachers College Press, 2007. p. 8-28.

TAMBOSI, H. H. F. Investigating language play in interaction: a qualitative study with children as foreign language learners. 2006. $111 \mathrm{f}$. Dissertação (Mestrado em Letras) - Universidade Federal de Santa Catarina, Florianópolis, 2006.

TONELLI, J. R. A. Histórias infantis no ensino da língua inglesa para crianças. 2005. 359 f. Dissertação (Mestrado em Estudos da Linguagem) Universidade Estadual de Londrina, Londrina, 2005.

TONELLI, J. R. A. Professores de língua adicional para crianças: atores de espaços vazios?. In: REIS, S. (Org.). Profissionalização docente: história, políticas e ética. 1. ed. Londrina: EDUEL, 2017. p. 67-84.

TONELLI, J.; QUEVEDO-CAMARGO, G. Avaliar crianças em fase préescolar aprendendo inglês como língua adicional: acertos e desacertos. In: Congresso Brasileiro de Linguística Aplicada, 11., 2016, Campo Grande. Anais... Campo Grande: 2016. p. 922-939. Disponível em:

〈http://www.alab.org.br/images/stories/alab/XICBLA/XI_CBLA.pdf〉. Acesso em: 30 nov. 2016.

TUTIDA, A. F. Ensino de língua inglesa para crianças: questões sobre formação de professores e os saberes da prática. 2016. 341 F. Dissertação (Mestrado em Estudos da Linguagem) - Universidade Estadual de Londrina, Londrina, 2016.

Submitted on: June 30, 2018 Accepted on: Oct 17, 2018

Título: Ensino de inglês como língua estrangeira para crianças: reflexões sobre o letramento em avaliação de línguas de (futuros) professores 
Teaching EFL to children...

Título: Enseñanza de Inglés como Lengua Extranjera a niños: reflexiones sobre la literacidad en evaluación de lenguas de (futuros) profesores 